\title{
Article \\ A Case Building Ciliate in the Genus Pseudoblepharisma Found in Subtropical Fresh Water
}

\author{
Hunter N. Hines ${ }^{1, *(\mathbb{D}) \text {, Peter J. McCarthy }}{ }^{1}\left(\mathbb{D}\right.$ and Genoveva F. Esteban ${ }^{2, *}$ \\ 1 Harbor Branch Oceanographic Institute, Florida Atlantic University, Fort Pierce, FL 34946, USA; \\ pmccart5@fau.edu \\ 2 Department of Life and Environmental Sciences, Faculty of Science and Technology, Bournemouth University, \\ Dorset BH12 5BB, UK \\ * Correspondence: hunter.n.hines@gmail.com (H.N.H.); gesteban@bournemouth.ac.uk (G.F.E.)
}

Citation: Hines, H.N.; McCarthy, P.J.; Esteban, G.F. A Case Building Ciliate in the Genus Pseudoblepharisma Found in Subtropical Fresh Water. Diversity 2022, 14, 174. https:// doi.org/10.3390/d14030174

Academic Editor: Michael Wink

Received: 16 December 2021

Accepted: 24 February 2022

Published: 27 February 2022

Publisher's Note: MDPI stays neutral with regard to jurisdictional claims in published maps and institutional affiliations.

Copyright: (C) 2022 by the authors. Licensee MDPI, Basel, Switzerland. This article is an open access article distributed under the terms and conditions of the Creative Commons Attribution (CC BY) license (https:// creativecommons.org/licenses/by/ $4.0 /)$.

\begin{abstract}
The genus Pseudoblepharisma is currently comprised of only one species, P. tenue, and one variant, $P$. tenue var. viride, both described as free-living ciliates thriving in oxygen depleted freshwater habitats of Europe. Here we report on this genus being discovered from subtropical freshwaters of Florida, USA. The Florida strain diverges from the $P$. tenue by being much larger, as well as having a far higher density of intracellular symbiotic green algae, resembling $P$. tenue var. viride. Unlike its European counterparts, the North American strain was observed to build a lorica, likely useful for protection and feeding; this has not been previously described for this genus. In contrast to P. tenue, the Florida strain does not have endosymbiotic purple bacteria. Despite large distances between sampling zones, the species is a close match at a morphological level to Pseudoblepharisma tenue var. viride. We provide the first $18 \mathrm{~S}$ rRNA gene sequence for this species, allowing future investigations into the biogeography of this genus. As intensive sampling efforts continue to increase, cryptic microbial species will continue to be recorded from diverse freshwater habitats at a global scale.
\end{abstract}

Keywords: biogeography; ciliate; cryptic biodiversity; ecology; freshwater; microbiology; protist

\section{Introduction}

The cryptic biodiversity of an environment is an important component of microbial food webs and the ecosystems they help to support [1,2]. Undersampling remains a persistent issue within microbial ecology $[3,4]$, such that the true diversity of a particular site or region is difficult to quantify. This results in many species remaining cryptic, especially when present in low numbers; however, they will also remain cryptic, even when present in astronomically high numbers, if the habitat is not studied [5]. This is frequently the case considering the number of unstudied habitats worldwide. Many species described as restricted to one area often have their biogeographical distribution expanded when intensive sampling efforts are conducted [6] and may be very common locally despite being previously unrecorded.

The genus Pseudoblepharisma comprises free-living freshwater ciliates originally documented from ponds in Europe (Germany) [7]. Blepharisma tenuis was the name used in the original German description of this genus [7]; however, this was quickly acknowledged to be incorrect, and it was fully rectified [8]. The genus was further described from the same geographical area, with descriptions of Pseudoblepharisma tenue presented [9]. This original work recorded the basic morphology, and it was later recorded (also in Germany) by Kreutz and Foissner (2006) [10], including the presence of intracellular algae and pink bacteria which were recognized not to be ingested but likely symbionts [8]. A detailed description of the German strain of $P$. tenue has recently been published [11], in which the use of single-cell genomics has allowed the identification of the symbionts, as well the determination of the draft genome for the ciliate. 
The ciliate Pseudoblepharisma tenue is the only species thus far described in the genus. The original observations [8] of P. tenue reported only a dozen endosymbiotic algal cells within the ciliate; the potential for the ciliate as being an example of an organism with mixed symbionts (algae and bacteria) was acknowledged due to the presence of 'pink' bacteria in the cytoplasm [8]. This combination of symbionts has been confirmed with the identification of bacteria closely related to the genus Thiodictyon, and eukaryotic algae closely related to the genus Chlorella thriving within P. tenue [11].

Pseudoblepharisma tenue var. viride is a variant recorded in the literature [10] which has, thus far, not benefited from a formal description and the possibility that this variant is a separate species to Pseudoblepharisma tenue must be considered.

Here, we report on the first record for the genus Pseudoblepharisma from North America, in subtropical fresh waters with this Florida strain most closely resembling Pseudoblepharisma tenue var. viride. The Florida strain is distinct morphologically and diverges at the molecular (18S rRNA gene) level from $P$. tenue.

\section{Materials and Methods}

\subsection{Study Sites}

Indrio Savannahs Preserve: $27^{\circ} 31^{\prime} 36.6^{\prime \prime} \mathrm{N} 80^{\circ} 21^{\prime} 47.7^{\prime \prime} \mathrm{W}$.

Habitat: shallow interconnected swampy wetland area in full sunlight, under the cover of large Nymphaeaceae (lily pads) to $60 \mathrm{~cm}$ depth (Figure 1A). Found within the light ('fluffy') organic sediments common in these habitats. Abundances of 10 to 50 cells per $\mathrm{mL}$ were encountered, with higher densities when top layer sediments were subsampled. All microscopy was conducted on samples from this location, with molecular sequencing also being undertaken only from this locality. This site was subjected to weekly intensive sampling for one year [12], with the site being investigated regularly from 2016 to 2021. The species was commonly found in samples taken from this habitat over this period. The normal water parameter measurements for this site during productive collections were: $\mathrm{pH}$ 6.2, dissolved oxygen (ODO through optical detection) $22 \%$ saturation, salinity 0.09 PSU (practical salinity units), temperature $28^{\circ} \mathrm{C}$.

The species was also found at two other Florida locations.

Blue Cypress Conservation Area: $27^{\circ} 39^{\prime} 48.6^{\prime \prime} \mathrm{N} 80^{\circ} 38^{\prime} 38.5^{\prime \prime} \mathrm{W}$. This site is a shallow canal with dense Nymphaeaceae (lily pads) leading to a large swamp area. The site is west $\sim 33 \mathrm{~km}$ inland from the Atlantic Ocean. At the time of sampling, the following water parameters were recorded: $\mathrm{pH} 7.26$, ODO $0.24 \%$ saturation, salinity $0.17 \mathrm{PSU}$, temperature $29^{\circ} \mathrm{C}$.

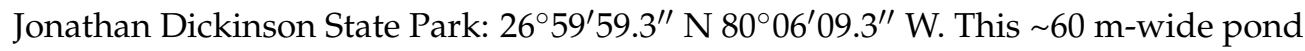
in full sunlight contained the species in similar abundance to the other Florida sites. At the time of sampling, the following water parameters were recorded: $\mathrm{pH} 6.79, \mathrm{ODO} 6.9 \%$ saturation, salinity $0.5 \mathrm{PSU}$, temperature $29^{\circ} \mathrm{C}$.

Both additional freshwater locations have loose sediments below Nymphaeaceae (lily pads) and overall appear very similar to the main locality. The two locations are $\sim 96 \mathrm{~km}$ apart, but are similar in their microbial consortia, plant, and sediment type. Jonathan Dickinson State Park is interesting in that it was the site of ordinance practice during WWII, ecological succession was then allowed to proceed undisturbed, and later the site was designated a State Park. The pond area sampled here formed in one of the pits created by the detonation of explosives. The pond and its microbial population has developed likely undisturbed over the last 75 years since the habitat was formed. 


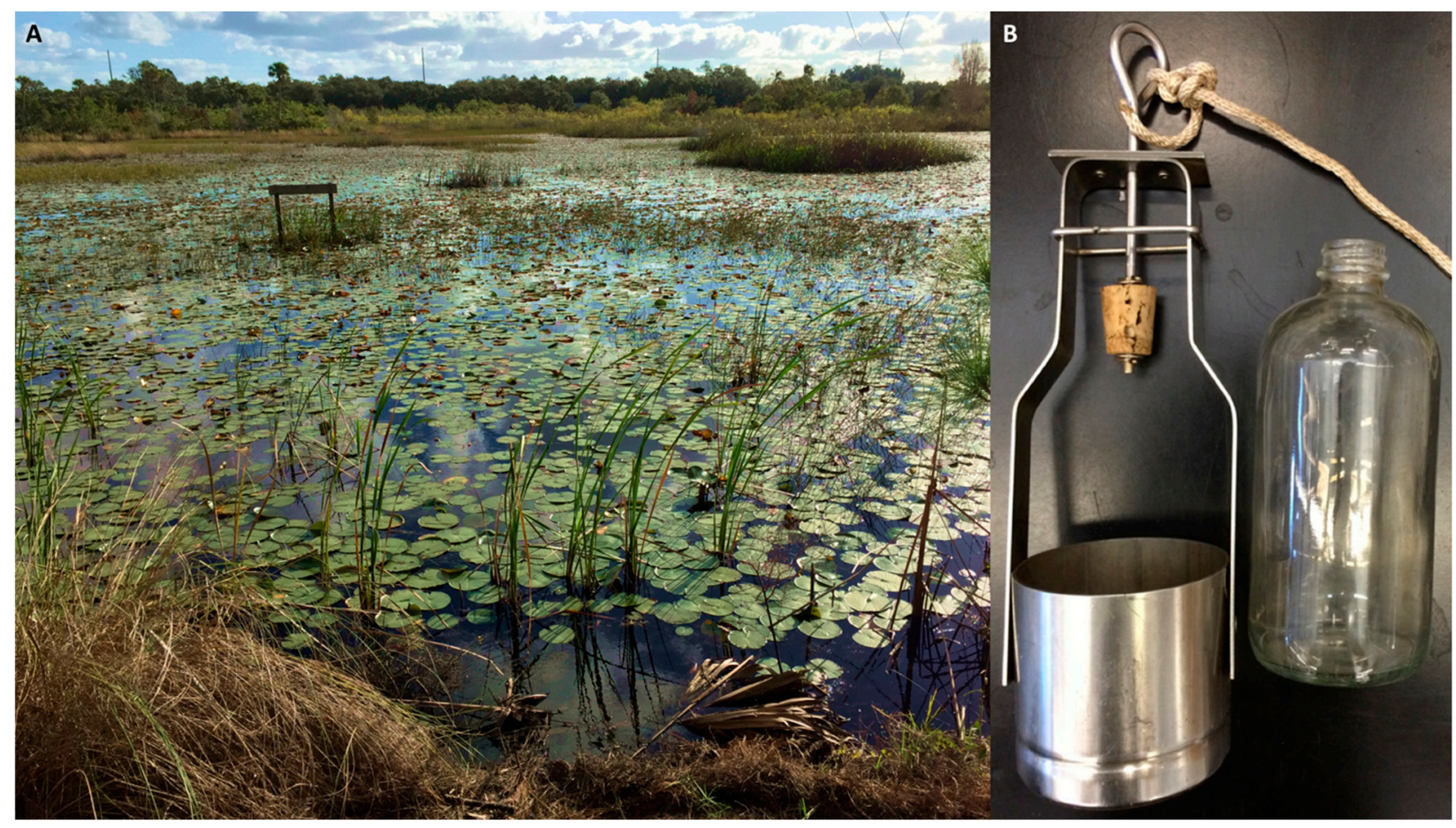

Figure 1. Florida sampling location and collection device. (A) Indrio Savannahs Preserve. This was the main sampling location investigated and the Florida habitat of Pseudoblepharisma. (B) Caged sampler with $500 \mathrm{~mL}$ bottle. This collecting apparatus was used for filling $500 \mathrm{~mL}$ sample bottles from all sites investigated. The weighted cage opens to allow the loading of a new bottle. The cork on a line mechanism allowed for it to be pulled within the site, obtaining a sample at the desired depth.

\subsection{Sample Collection}

A caged corked bottle sampler (CONBAR ep, Monroeville, NJ, USA) housing an interchangeable $500 \mathrm{~mL}$ glass 'Boston round' bottle with a $10 \mathrm{~m}$ line was used to collect the water and sediment (Figure 1B). The sampler was deployed on a line into the area of the waterbody being sampled. Once submerged, the cork stopper was removed by a sharp tug on the line allowing the bottle to fill with water and sediment at the desired depth $[12,13]$. The sampler was then retrieved, and the bottle removed and capped for transport to the lab. Sampling of the sites involved the use of 5 to 15 bottles in order to obtain a wide representation of the microbial communities present at the site. The device was washed between collections and was rinsed with $70 \%$ ethanol on return to the laboratory. Bottles were autoclaved before reuse.

\subsection{Measurement of Site Metadata}

A ProDSS YSI (four port "Digital Professional Series" by Xylem, Yellow Springs, OH, USA) was used to measure site metadata, equipped with probes to obtain $\mathrm{pH}$, conductivity (measured in PSU), temperature, and dissolved oxygen data. The size of the YSI sensor probe was $35 \mathrm{~cm}$. The probe was deployed so that it would lay submerged horizontally on the sediment substrate. This was close to the zones sampled using the $500 \mathrm{~mL}$ bottle sampler. The probe was allowed to settle for at least $30 \mathrm{~s}$ before a reading was taken. The probe was washed in deionized $\mathrm{H}_{2} \mathrm{O}$ between sites.

\subsection{Microscopy}

Individual ciliates were picked using a micropipette under a dissecting microscope for use in PCR, or onto welled slides for examination under higher powered microscopy (Figure 2). Initial observations were made using a $1 \mathrm{~mL}$ Sedgewick-Rafter counting chamber which allowed observation, enumeration, and photography. 
An Olympus BX-53 microscope was used for detailed observation and for taking micrographs. An Olympus DP72 camera attached directly to the microscope was used to record the images of the ciliates, measurements were taken using the Olympus cellSens software package (version 1.17; Olympus Life Sciences, Center Valley, PA, USA).

\subsection{DNA Extraction and Amplification}

Although these ciliates were most often found within their natural habitat of sediments, certain conditions within the $500 \mathrm{~mL}$ sample bottles occurred that forced the species up into the water column. The reasons for this could be many [14], with reaction to oxygen levels being most likely for this movement. After some time (usually between 48 and $100 \mathrm{~h}$ ) an almost pure green layer of cells would be observed near the top of some sample bottles; this was used for picking for molecular sequencing as the ciliates were more readily sampled and cleaner than when dwelling within the sediments.

A REDExtract-N-Amp PCR ReadyMix (Sigma-Aldrich, St. Louis, MO, USA) was used to both extract and amplify the ciliate sample. The method followed that described in the literature [15]. In a single tube, $100 \mu \mathrm{L}$ of extraction solution was mixed with $25 \mu \mathrm{L}$ of tissue prep solution. The mixture was then added to each of 10 tubes ( $12.5 \mu \mathrm{L}$ to each), containing 1 previously selected, picked, and washed ciliate (as described above) which was then vortexed for $5 \mathrm{~s}$. The tubes were incubated for $10 \mathrm{~min}$ at ambient temperature and then heated in a dry bath incubator (Fisher Scientific, Hampton, NH, USA) for 3 min at $95^{\circ} \mathrm{C}$. Neutralization Solution $(10 \mu \mathrm{L})$ was then added to each tube and thoroughly mixed. Samples were either amplified immediately or stored at $-20{ }^{\circ} \mathrm{C}$.

To amplify the $18 \mathrm{~S}$ rRNA gene the primers 'Euk-82F' (GAA ACT GCG AAT GGC TC) and 'EukB' (TGA TCC TTC TGC AGG TTC ACC TAC) were used [16,17]. A master mix was prepared by combining $52 \mu \mathrm{L}$ of sterile DI $\mathrm{H}_{2} \mathrm{O}, 100 \mu \mathrm{L}$ REDExtract-N-Amp PCR reaction mix, and $4 \mu \mathrm{L}$ of each primer $(10 \mu \mathrm{M})$ in a sterile tube. Master mix $(16 \mu \mathrm{L})$ was pipetted into each PCR tube to which $4 \mu \mathrm{L}$ of the individual DNA extract (described above) was added. The PCR protocol was as follows: 9 cycles of denaturation $\left(94{ }^{\circ} \mathrm{C}, 40 \mathrm{~s}\right)$, annealing $\left(55^{\circ} \mathrm{C}\right.$, for $\left.40 \mathrm{~s}\right)$, extension $\left(72{ }^{\circ} \mathrm{C}, 2 \mathrm{~min}\right)$ followed by 45 cycles of denaturation $\left(92{ }^{\circ} \mathrm{C}, 40 \mathrm{~s}\right)$, annealing $\left(55^{\circ} \mathrm{C}\right.$, for $\left.40 \mathrm{~s}\right)$, extension $\left(72{ }^{\circ} \mathrm{C}, 2 \mathrm{~min} 30 \mathrm{~s}\right)$, then a final incubation step $\left(72^{\circ} \mathrm{C}\right.$, $6 \mathrm{~min})$.

PCR products were visualized on a 1\% agarose gel and purified using a GenCatch Purification Kit (Epoch Life Sciences, Houston, TX, USA) following manufacturer's directions. Sanger sequencing of the amplicon was performed by MCLab (South San Francisco, CA, USA). A sequence for the $18 \mathrm{~S}$ rRNA gene from a single cell was obtained and deposited into GenBank FL1 MK543441 (1597 bp).

\subsection{Phylogenetic Analysis}

The newly sequenced SSU rDNA of Pseudoblepharisma tenue, 46 Heterotrich ciliate sequences for the genera Spirostomum, Anigsteinia, and Blepharisma obtained from Genbank (Accession numbers are included in Figure 3), and Pseudoblepharisma tenue MG01 (18S sequence provided by pers coms. Muñoz-Gómez, from their draft genome deposited in NCBI GenBank under the BioProject PRJNA664598 [11]) were used to infer the phylogenetic relationships of Pseudoblepharisma. Two species of Blepharisma were used for the outgroupB. halophilum and B. japonicum. Evolutionary analyses were conducted in MEGA-X (version 10.0.5) [18]. The sequences were aligned using the MUSCLE program and manually edited to achieve a better alignment. The evolutionary history was inferred by using the maximum likelihood method and the Tamura-Nei model [19]. The tree with the highest log likelihood $(-6176.12)$ is shown. The percentage of replicate trees in which the associated taxa clustered together in the bootstrap test (1000 replicates) are shown next to the branches [20]. Initial tree(s) for the heuristic search were obtained automatically by applying neighbor join and BioNJ algorithms to a matrix of pairwise distances estimated using the maximum composite likelihood (MCL) approach, and then selecting the topology with superior log likelihood value. The tree is drawn to scale, with branch lengths measured in the number of 
substitutions per site. This analysis involved 48 nucleotide sequences. There was a total of 1800 positions in the final dataset. The tree was edited for publication using the Interactive Tree of Life (iTOL) v5 [21].

\section{Results}

An approximately $400 \mu \mathrm{m}$ freshwater ciliate that builds a protective case, or lorica, and contains dense green symbiotic algae was discovered at three Florida sites (Table 1, Figure 2). The cell had a long adoral zone of membranelles (AZM), and a single, oval macronucleus with a single micronucleus. The ciliate was highly contractile, and this ability-along with the symbiotic algae-initially pointed to the identification of a ciliate in the genus Spirostomum. The ciliate species Spirostomum semivirescens is highly contractile, densely packed with symbiotic green algae, and is known to build a protective coating [6,22]. Further taxonomic investigation allowed the identification of the Florida ciliate as being a species within the rarely recorded genus Pseudoblepharisma, such as the species Pseudoblepharisma tenue var. viride [10] due to the cell size and overall shape, along with the presence of dense symbiotic green algae (Figure 2).

Table 1. Diagnostic features of the Florida Pseudoblepharisma tenue var. viride representative. Measurements were done on 30 freshly collected individual cells.

\begin{tabular}{lc}
\hline & Pseudoblepharisma tenue var. viride \\
\hline Location & Florida \\
\hline Cell length $(\mu \mathrm{m})$ & $310-480$ (mean 410) \\
\hline Cell width $(\mu \mathrm{m})$ & $38-50$ (mean 40) \\
\hline Macronucleus 1 $(\mu \mathrm{m})$ & $\sim 30$ \\
\hline Micronucleus 1 $(\mu \mathrm{m})$ & $\sim 6$ \\
\hline Contractile vacuole & Present \\
\hline Color & Green \\
\hline Symbiotic algae & Present \\
\hline Purple bacteria & Absent \\
\hline Molecular sequence & MK543441 \\
\hline Case-building & Present \\
\hline
\end{tabular}

The ciliate has an oval shaped nuclear apparatus similar to Spirostomum teres [23], with an AZM up to one-half to one-third of the ciliate's body length (Figure 2). The single terminal contractile vacuole is clear and can somewhat deform the cell. No cysts were observed from the Florida strain.

Non-pigmented rod-shaped bacteria with a length of $\sim 8 \mu \mathrm{m}$ were observed when a cell lysed (Figure 2A), suggesting their presence within the cytoplasm (Figure 2B). The bacteria were not identified; however, no purple-pigmented bacteria were observed within the Florida strain cells.

The cell was densely packed with hundreds of symbiotic algae cells similar in appearance to that observed in Spirostomum semivirescens from Europe [6]. Targeted molecular sequencing of the algal symbiont was not undertaken.

This Florida ciliate was always found in rich organic sediment along with other green ciliates (such as Frontonia, Prorodon spp.). The ciliate is mixotrophic in that it filter-feeds on bacteria from the water while hidden in its lorica, and it also likely receives nutrients from its algal symbionts, a relationship well documented in ciliates [1,24]. The lorica was readily observed in $1 \mathrm{~mL}$ counting chambers when the ciliates were left undisturbed with some sediment for approximately one hour, which gave them time to build a new protective case (Figure 2D). 


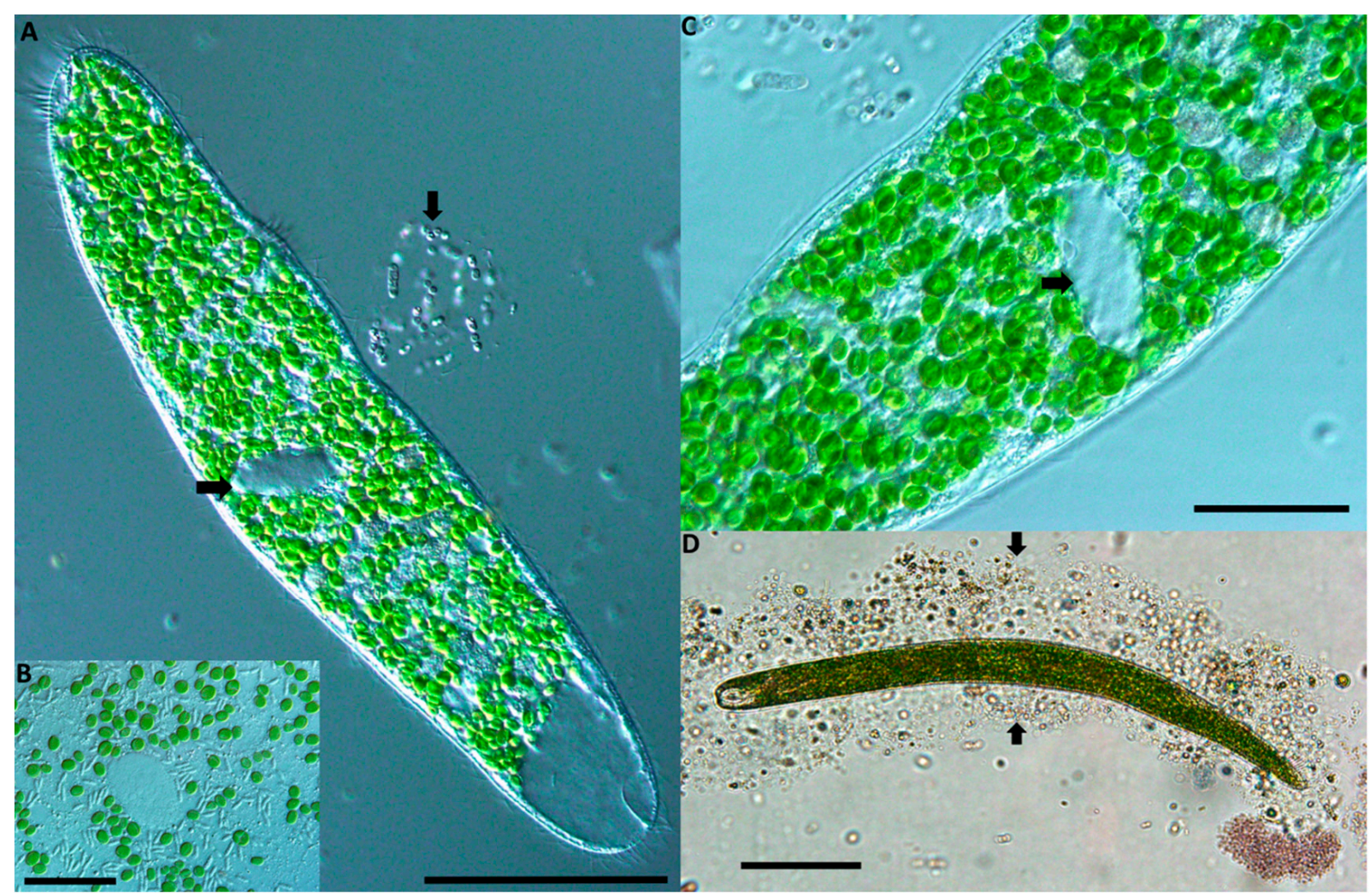

Figure 2. Pseudoblepharisma tenue var. viride from tropical fresh waters in Florida, USA. (A) In vivo image of the ciliate showing dense assemblage of symbiotic green algae. The arrow at left indicates the oval macronucleus. The small arrow at right shows a cloud of bacteria which has come off the ciliate, potentially symbiotic in the cytoplasm. The large clear contractile vacuole is conspicuous at the posterior end of the cell (bottom right of image). Scale bar: $100 \mu \mathrm{m}$. (B) Close-up of the macronucleus (clear oval) surrounded by symbiotic algae resembling Chlorella. Numerous non-pigmented rodshaped bacteria are also shown here. Scale bar: $20 \mu \mathrm{m}$. (C) Close-up section of the ciliate with an arrow indicating the singular large oval shaped macronucleus. Directly above the arrow is the small micronucleus. The circular symbiotic algae are densely packed throughout the cytoplasm. Scale bar: $20 \mu \mathrm{m}$. (D) In vivo image of the ciliate after it was picked and left undisturbed on a slide for $\sim 1 \mathrm{~h}$. The two arrows indicate either side of a casing the ciliate has made and rests entirely within. Scale bar: $100 \mu \mathrm{m}$.

The ciliate survives for several days in a closed $500 \mathrm{~mL}$ bottle at room temperature $\left(\sim 25^{\circ} \mathrm{C}\right)$, shaded from artificial overhead light. The ciliate also survived in a $30^{\circ} \mathrm{C}$ incubation chamber, however, no enhanced population growth was detected. All observations were made on living cells, as the ciliate was not established in culture.

The ability of this ciliate to rapidly contract is readily observed on a $1 \mathrm{~mL}$ chamber slide. The lorica is essentially a mucilage-like case built with sediment particles (Figure 2D). The ciliate moves such that from the lorica it pokes out its anterior end to filter feed, and when disturbed retreats back into the casing which covers the entire cell. The case building was recorded from all three Florida sites. The ciliate is sensitive and quickly reacts to vibrations, by contracting rapidly, either into the lorica or when free-swimming, similar to behavior observed in the European S. semivirescens $[1,6]$. The Florida species does not obviously react to light, unlike $S$. semivirescens found in the UK, which rapidly contracts from sudden illumination with bright light.

An analysis of the 18S rRNA gene molecular phylogeny (Figure 3) places our MK543441 with the European P. tenue MG01 with a $98 \%$ match in the gene sequence. P. tenue clusters with the two clades of Spirostomum as a closely related but distinct early branching lineage. Anigstenia and Blepharisma are placed on the tree as members of the family Blepharismi- 
dae [25]; they branch distinctly from the Pseudoblepharisma/Spirostomum clades on this tree (Figure 3).

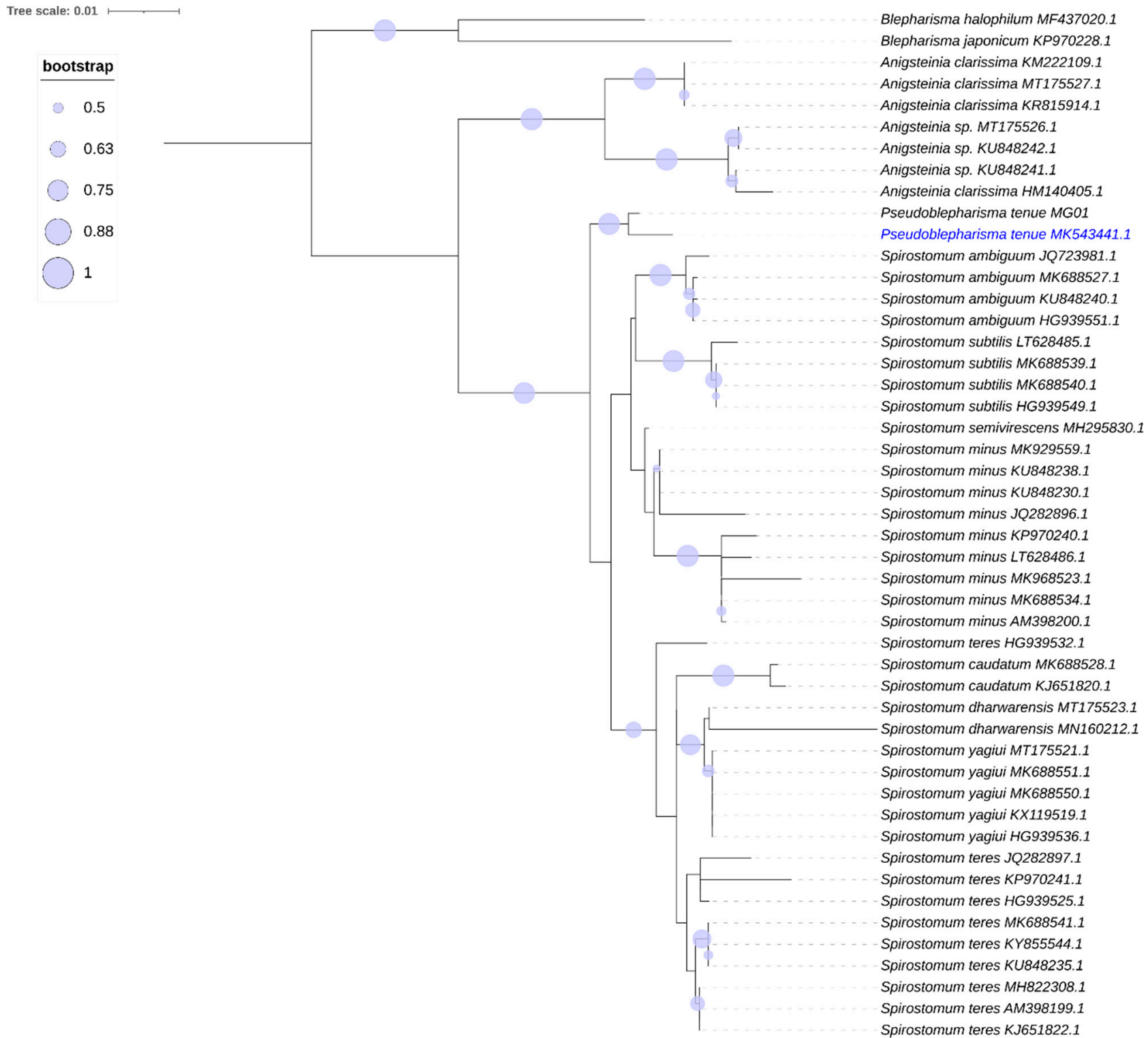

Figure 3. Phylogenetic tree showing Pseudoblepharisma tenue var. viride. Maximum likelihood (ML) tree inferred from SSU rDNA sequences showing the systematic position of Pseudoblepharisma tenue (blue text, MK543441). ML Bootstrap values are indicated by the size of the blue circles. The bar corresponds to 1 substitution per 100 nucleotides.

\section{Discussion}

Pseudoblepharisma is a heterotrich ciliate which had been recorded previously only from freshwater habitats in Germany $[10,11]$. The original descriptions referred to the presence of purple bacteria present in the ciliate cytoplasm and were suggested to be symbiotic [8]. Since this work, further investigations into this genus and its symbiotic microbial consortia have been undertaken [11], confirming the presence of a combination of symbionts inside the ciliate host. Pseudoblepharisma tenue from Europe was often found to be purple [10,11], which was never observed for the Florida populations. The original descriptions from Germany of Pseudoblepharisma tenue [7-9] somewhat match the Florida strain on a basic morphological level; however, the previous records do not mention the ciliate's lorica 
building, which was commonly observed within Florida samples, with cases observed in each $1 \mathrm{~mL}$ water-sediment subsample that also contained the ciliate.

The Florida strain also differs from the European Pseudoblepharisma tenue records in the absence of purple bacteria in the cytoplasm and the much higher densities of symbiotic green algae (hundreds vs. a scattered dozen). The Florida cells are also more than double the length of most of the European recorded cells. The strain recorded in Florida may either be Pseudoblepharisma tenue var. viride or a previously unobserved variation.

In the recent study of German samples, six cells of $P$. tenue were measured with a mean length of $182 \mu \mathrm{m}$ [11], which is considerably smaller than the $410 \mu \mathrm{m}$ mean recorded from the 30 cells measured in Florida samples. The original descriptions report cell lengths of $100-150 \mu \mathrm{m}$ [7] and a scrutinized cell was reported as $200 \mu \mathrm{m}$ [8]. A cell of about $300 \mu \mathrm{m}$ was reported for Pseudoblepharisma var. viride, with the imagery showing densely packed symbiotic green algae more similar to the Florida strain [10]. Differences in habitat type could account for these differences, with subtropical habitats such as those investigated in Florida often containing larger cells than found in colder areas [26].

The $18 \mathrm{~S}$ rRNA gene sequence for the Florida strain of P. tenue var. viride (MK543441) shows a 98\% match to Pseudoblepharisma tenue MG01 [11], suggesting some degree of taxonomic variation. However, no molecular analysis has yet been carried out on any other $P$. tenue var. viride strains, and no conclusions should be drawn from two sequences. It may be that $P$. tenue var. viride is simply an ecological form of $P$. tenue. The number of endosymbiotic algae in several ciliate species has been observed to vary seasonally; this is the case of Loxodes rostrum and Euplotes daidaleos (personal observations), both species showing very low numbers of green endosymbionts in winter months, when temperatures are low and day light is short. Future morphological and molecular analysis of $P$. tenue and $P$. tenue var. viride will bring further taxonomic clarity.

Purple bacteria were not observed in the Florida Pseudoblepharisma populations. The non-pigmented bacteria observed in association with Florida Pseudoblepharisma have not yet been identified. The absence of purple bacteria is reflected in the color difference noted between cells from Florida (green) and P. tenue from Europe.

The German habitat of this genus [10,11] is the sphagnum ponds of the Simmelried, a three-hectare moorland and sphagnum swamp in Southern Germany with a reported $\mathrm{pH}$ between ponds of 5-7 [10]. The water is known to freeze over in winter, with the collection areas for this genus being described as microaerobic, with Pseudoblepharisma being reported as an indicator of these low oxygen conditions [27]. The Florida population of Pseudoblepharisma thrives in low-oxygen warm waters $\left(25-30^{\circ} \mathrm{C}\right)$ within the sedimentwater interface layer, without such common extremes of cold. The habitat in Germany formed after the last ice age 15,000 years ago and is interesting in that it has accumulated a large diversity of protists [10] in a geologically short period of time, similar to the timing for formations of freshwater habitats in Florida [28,29]. The primary sampling habitat, Indrio Savannahs Preserve, is a 297-acre nature reserve that is essentially a nutrient-poor, scrubby flatwoods containing a basin and depression swamp which is a conservationally restored natural freshwater drainage area.

The Florida strain was recorded consistently during intensive sampling between 2016-2019 [12]. During this time, the type locality dried completely, before flooding after Hurricane Irma deposited substantial water within the system in 2017. The target ciliate was recorded so regularly before the drought event that it was considered common in this habitat; it was again recorded with similar high frequency shortly after the 2017 Hurricane Irma (and beyond), showing the resilience of microbial communities. The fact that this species was common and recorded in such high numbers provides an example of the importance of intensive sampling before any conclusion on the biogeography of the group is reached. It is likely that other less obvious and less common species exist in these same habitats but were undetected despite long term intensive efforts.

While no cysts were observed in Florida samples, thin-walled resting cysts have been reported for P. tenue [11]. The protective lorica of the Florida strain may aid in dispersal 
(e.g., wind, birds, reptiles) of the cell, as well as its survival during unfavorable conditions such as drought, similar to the ciliate Spirostomum semivirescens [6]. It is unclear whether lorica-protected ciliates survived in the study site during drought conditions or were rapidly dispersed from other populations after water levels returned. It is possible that these cells do form a cyst, which was not observed during this investigation.

The topology of the phylogenetic tree (Figure 3) indicates a very close relationship between Pseudoblepharisma and Spirostomum, matching the similarities observed in their morphology and habitat. Further molecular and morphological investigations of other strains of P. tenue and P. tenue var. viride from Europe and other worldwide locations will advance the understanding of this species and determine whether the genera Pseudoblepharisma and Spirostomum should be considered synonymous.

\section{Conclusions}

The discovery of Pseudoblepharisma from a new biogeographical location further highlights the consequences of undersampling $[3,4,30,31]$ and the need to study and protect habitats for their microbial consortia.

The genus Pseudoblepharisma has existed cryptically in North America until recently, being recorded in Florida $(>7500 \mathrm{~km}$ distance from the original genus discovery site in Europe). The strain of Pseudoblepharisma discovered in Florida was similar to existing diagnostics from Europe [8], particularly to $P$. tenue var. viride, i.e., size and density of endosymbiotic green algae. However, the presence of a lorica has not yet been observed in European populations. The $18 \mathrm{~S}$ rRNA gene sequence was similar to those reported in the literature for this genus and for the genus Spirostomum. Further molecular studies at a global level will help resolve whether these genera are synonyms, and future intensive sampling will likely reveal additional species to this genus.

Author Contributions: Conceptualization, H.N.H., G.F.E. and P.J.M.; methodology, H.N.H., G.F.E. and P.J.M.; Investigation, H.N.H., P.J.M. and G.F.E.; writing—original draft preparation, H.N.H.; writing - review and editing, G.F.E. and P.J.M. All authors have read and agreed to the published version of the manuscript.

Funding: This research received no external funding.

Institutional Review Board Statement: Not applicable.

Data Availability Statement: Not applicable.

Acknowledgments: We would like to thank Sergio A. Muñoz-Gómez and collaborators for sharing data for their Pseudoblepharisma tenue strain.

Conflicts of Interest: The authors declare no conflict of interest.

\section{References}

1. Esteban, G.F.; Fenchel, T.; Finlay, B.J. Mixotrophy in ciliates. Protist 2010, 161, 621-641. [CrossRef] [PubMed]

2. Esteban, G.; Finlay, B.J. Conservation work is incomplete without cryptic biodiversity. Nature 2010, 463, 293. [CrossRef]

3. Finlay, B. Global dispersal of free-living microbial eukaryote species. Science 2002, 296, 1061-1063. [CrossRef] [PubMed]

4. Hines, H.N.; McCarthy, P.J.; Esteban, G.F. The first record for the Americas of Loxodes rex, a flagship ciliate with an alleged restricted biogeography. Microb. Ecol. 2016, 71, 5-8. [CrossRef]

5. Finlay, B.; Esteban, G.; Fenchel, T. Protist diversity is different? Protist 2004, 155, 15. [CrossRef] [PubMed]

6. Hines, H.N.; Onsbring, H.; Ettema, T.J.; Esteban, G.F. Molecular investigation of the ciliate Spirostomum semivirescens, with first transcriptome and new geographical records. Protist 2018, 169, 875-886. [CrossRef] [PubMed]

7. Kahl, A. Neue und wenig bekannte Formen der holotrichen und heterotrichen Ciliaten. Arch. Protistenk 1926, 55, 197-438.

8. Kahl, A. Neue und ergänzende Beobachtungen heterotricher Ciliaten. Arch. Protistenk 1927, 57, 121-203.

9. Kahl, A.; Urtiere oder Protozoa, I. Wimpertiere oder Ciliata (Infusoria). 3. Spirotricha. Die Tierwelt Deutshlands Und Der Angrenz. Meerest. 1932, 25, 399-650.

10. Kreutz, M.; Foissner, W. The Sphagnum Ponds of Simmelreid in Germany: A Biodiversity Hot-Spot for Microscopic Organisms; Shaker Verlag Aachen: Düren, Germany, 2006; 267p.

11. Muñoz-Gómez, S.A.; Kreutz, M.; Hess, S. A microbial eukaryote with a unique combination of purple bacteria and green algae as endosymbionts. Sci. Adv. 2021, 7, eabg4102. [CrossRef] 
12. Hines, H.N. The Biogeography, Phylogeny, and Dispersal of Freshwater and Terrestrial Free-Living Ciliates in Florida, USA. Ph.D. Dissertation, Bournemouth University, Bournemouth, UK, 2019.

13. Brave Wilderness. "I Caught Brain Eating Amoeba!” YouTube. 26 June 2021. Available online: https://youtu.be/XdXgs-kxxFU (accessed on 15 December 2021).

14. Finlay, B.; Berninger, U.; Stewart, L.; Hindle, R.; Davison, W. Some factors controlling the distribution of two pond-dwelling ciliates with algal symbionts (Frontonia vernalis and Euplotes daidaleos). J. Protozool. 1987, 34, 349-356. [CrossRef]

15. Kim, S.; Min, G. Optimization of DNA extraction from a single living ciliate for stable and repetitive PCR amplification. Anim. Cells Syst. 2009, 13, 351-356. [CrossRef]

16. Elwood, H.; Olsen, G.; Sogin, M. The small-subunit ribosomal RNA gene sequences from the hypotrichous ciliates Oxytricha Nova Stylonychia Pustulata. Mol. Biol. Evol. 1985, 2, 399-410. [PubMed]

17. Medlin, L.; Elwood, H.; Stickel, S.; Sogin, M. The characterization of enzymatically amplified eukaryotic 16S-like rRNA-coding regions. Gene 1988, 71, 491-499. [CrossRef]

18. Kumar, S.; Stecher, G.; Li, M.; Knyaz, C.; Tamura, K. MEGA X: Molecular Evolutionary Genetics Analysis across computing platforms. Mol. Biol. Evol. 2018, 35, 1547-1549. [CrossRef] [PubMed]

19. Tamura, K.; Nei, M. Estimation of the number of nucleotide substitutions in the control region of mitochondrial DNA in humans and chimpanzees. Mol. Biol. Evol. 1993, 10, 512-526. [PubMed]

20. Felsenstein, J. Confidence limits on phylogenies: An approach using the bootstrap. Evolution 1985, 39, 783-791. [CrossRef] [PubMed]

21. Letunic, I.; Bork, P. Interactive Tree Of Life (iTOL) v5: An online tool for phylogenetic tree display and annotation. Nucleic Acids Res. 2021, 49, W293-W296. [CrossRef]

22. Esteban, G.F.; Bradley, M.; Finlay, B. A case-building Spirostomum (Ciliophora, Heterotrichida) with zoochlorellae. Eur. J. Protistol. 2009, 45, 156-158. [CrossRef] [PubMed]

23. Boscaro, V.; Carducci, D.; Barbieri, G.; Senra, M.V.; Andreoli, I.; Erra, F.; Petroni, G.; Verni, F.; Fokin, S.I. Focusing on genera to improve species identification: Revised systematics of the ciliate Spirostomum. Protist 2014, 165, 527-541. [CrossRef] [PubMed]

24. Esteban, G.F.; Fenchel, T. Ecology of Protozoa: The Biology of Free-Living Phagotrophic Protists, 2nd ed.; Springer Nature: Cham, Switzerland, 2020.

25. Lynn, D. The Ciliated Protozoa: Characterization, Classification, and Guide to the Literature; Springer Science \& Business Media: New York, NY, USA, 2008; ISBN 978-1-4020-8238-2.

26. Dragesco, J.; Dragesco-Kernéis, A. Ciliés Libres de L'Afrique Intertropicale; Editions de l'Orstom XXVI Faune Tropicale: Paris, Frence, 1986; Volume 26, pp. 1-559. ISBN 2-7099-0750-X.

27. Kreutz, M.; Stoeck, T.; Foissner, W. Morphological and Molecular Characterization of Paramecium (Viridoparamecium nov. subgen.) chlorelligerum Kahl (Ciliophora). J. Eukaryot. Microbiol. 2012, 59, 548-563. [CrossRef]

28. Watts, W. A pollen diagram from Mud Lake, Marion County, north-central Florida. Geol. Soc. Am. Bull. 1969, 80, 631-642. [CrossRef]

29. Watts, W. A late Quaternary record of vegetation from Lake Annie, south-central Florida. Geology 1975, 3, 344-346. [CrossRef]

30. Caron, D. Past President's address: Protistan biogeography: Why all the fuss? J. Eukaryot. Microbiol. 2009, 56, 105-112. [CrossRef] [PubMed]

31. Foissner, W.; Chao, A.; Katz, L. Diversity and geographic distributions of ciliates (Protista: Ciliophora). Biodivers. Conserv. 2008, 17, 345-363. [CrossRef] 